\title{
Peertechz
}

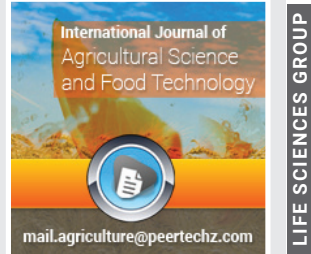

Review Article

\section{Physico-chemical properties of Ethiopian Apis mellifera Honey: Review}

\section{Sintayehu Berhanu, Dereje Mamo Tadesse* and Amauel Jorge}

Department of Chemistry, Bonga University, Bonga, P.O. Box 334, Bonga, Ethiopia

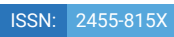

Received: 23 November, 2021

Accepted: 18 January, 2022

Published: 19 January, 2022

*Corresponding author: Dereje Mamo Tadesse Department of Chemistry, Bonga University, Bonga, P.O Box 334, Bonga, Ethiopia, Tel: +251934111956; E-mail: derejemao.chem21@gmail.com

ORCID: https://orcid.org/0000-0003-1951-7301

Keywords: Ethiopia; Honey; Physicochemical properties; Antioxidant properties

Copyright License: (c) 2022 Berhanu S, et al. This is an open-access article distributed under the terms of the Creative Commons Attribution License, which permits unrestricted use, distribution, and reproduction in any medium, provided the original author and source are credited.

https://www.peertechzpublications.com

\section{Abstract}

The aim of this review is focused on the physical, chemical, and antioxidant properties of Ethiopian honey such as moisture contents, reducing sugars (glucose and fructose), free acidity, pH, hydroxymethylfurfural, (HMF), phenolic compounds, minerals, and water-insoluble solid and enzymatic activity of honey. Generally, the average values of the parameter were within the acceptable ranges of National, EU, and FAO/WHO which was set as permission limit requirement for general blossom honey quality. Accordingly, HMF $(9.46 \pm 7.11 \mathrm{mg} / \mathrm{kg})$, moisture contents $(18.93 \% \pm 1.92 \%)$, free acidity $(23.2 \pm 10 \mathrm{meq} / \mathrm{kg})$, pH $(3.94 \pm 0.14)$ ash content $(0.32 \% \pm 0.13 \%)$, electrical Conductivity $(0.41 \pm 0.16 \mathrm{mS} / \mathrm{cm})$, water-insoluble solids $(0.20 \% \pm 0.07 \%)$, reducing Sugar $(70.46 \% \pm 3.5,0 \%)$, and Sucrose $(2.75 \% \pm 1.1 \%)$ of the honey was found to be low, this value suggesting that Ethiopian honey were of good quality. The total phenolic contents of honey were high and strongly correlated with the antioxidant activity/ radical scavenging capacity. A large portion of research findings are not focused on medicinal value therefore, more research would be important to focus on honey from medicinal plants and to build up the possible relations between the bioactive substances in plant parts and their nectars.

\section{Introduction}

Honey is a natural substance delivered by honeybees from the nectar of blossom which is gathered from various plants and popular world widely due to its high healthful and therapeutic qualities [1]. The chemical, physical, antioxidant, and healthful composition of honey varies depending upon flower source, soil type, geological root, and climatic condition CACS (2001). Both old and present-day civilizations utilize honey as a remedy for different illnesses. It is also delectable food, for the most part, made out of sugars and different constituents like proteins, organic acids, amino acids, nutrients, minerals, carotenoids and aromatic substances. It is wealthy in flavonoids and phenolic acids that display a wide scope of biological impacts and act as natural antioxidants arabagias, et al. 2014) [2].

Honey is composed of nutritive polyphenols [3]. Polyphenols are primary identifying markers for the botanical origin of honey [4], and they display high therapeutic and dietary value [5]. The major polyphenol compounds in honey are flavonoids and phenolic acid [6]. Flavonoids and phenolic acid are responsible for inhibiting oxidation and destroying free radicals [7].

The quality parameter and uniqueness of honey are examined by different researchers. The quality and validity of food play out a significant role for the two, buyers and producers. A significant concern of honey quality is to guarantee that honey is authentic in regard to the legislative necessities. Authenticity is identified with the judgments of topographical and floral origins and the discovery of unapproved substances $[8,9]$.

Ethiopia and Egypt are some of the main countries in working honey beekeeping (Abera, et al. 2013). The world production of honey was around 1,800,000 tonnes; Ethiopia is the primary honey maker in Africa, and one of the ten biggest honey-producing nations in the world. The total number 
of beehives in Ethiopia is 5,207,300 of which $95.96 \%$ are traditional and $2.98 \%$ are frame hives [10]. The most widely known honey plants, which are used as a source of nectar and pollen, are Guizotia scabra and Guizotia. abyssinica, Eucalyptus globulus, Sheffleria abyssinica, Vernonia species, Syzygium guineense, Acacia species, Croton machrostachyus, and Erica arborea $[11,12]$.

Since physicochemical parameters are very important for the honey industry. These are minerals, moisture content, reducing sugars, electrical conductivity, free acidity, sucrose content, and Hydroxymethylfurfural (HMF), which have an impact on the quality of nutrition, granulation, and quality of storage, flavor, and texture of the honey. These components are also responsible for the medicinal value of honey. The ultimate goal of characterizing the physicochemical and antioxidant proprieties of honey is used to verify the authenticity of the product, to reveal the possible presence of artificial components or adulterants and their contribution to the human health benefits $[8,13]$.

The antioxidant properties of honey are believed to be at the heart of their polyphenolic compounds. Ethiopian natural honey and propolis are thought to be of different varieties due to the unique and highly diverse flora of the country because of its rich variety of environmental features ranging from semidesert to mountain forests and its wide range of ecological, edaphic, and climatic conditions [11].

However, the physicochemical and antioxidant properties of natural honey are various due to botanical, bee species, climate, agricultural practices, geographical origin, seasonal conditions and environmental factors [13]. As a result, the present review was focused on parameters for honey quality: moisture contents, reducing sugars (glucose and fructose), Hydroxymethylfurfural (HMF), free acidity, phenolic compound, enzymatic activity, $\mathrm{pH}$, ash content, minerals, and water-insoluble solid of honey in Ethiopia. Today the event of antibiotic-resistant pathogens poses a serious risk to public health, thus a high demand for an alternative to antibiotics and conventional therapies is increasing more than ever [14]. This generally shows the importance of screening of different floral origin honey and identifies the one with more antimicrobial potencies.

\section{Method of review}

For information assortment, Google Scholar, PubMed, and Science Direct were freely looked. The entirety of the accessible reports on the physicochemical properties of honey which made in Ethiopia a writing search was finished by utilizing the Scopus information base with the mix of the accompanying arrangements of two keywords; Honey with a combination of physical, chemical, or physicochemical properties. Consideration was made on physicochemical properties, for example, moisture content, electrical conductivity, sugars profile, enzyme activity, $\mathrm{pH}$, and main antioxidant of Ethiopian honey.

Information was analyzed and summarized using SPSS version: 20. Different researcher utilizes different values for reporting data; to decrease prejudice average mean value was taken. The outcome compared with National, FAO/WHO, and EU which set as consent limited by Codex Alimentarius (2001) and the Council of the European Union [15] for honey quality.

\section{Physicochemical properties}

The physicochemical properties of honey informed essentially vary by every researcher and two indistinguishable honeys never have similar properties due to differentiation in species, variety of greenery, and different geographical origin and climatic condition. Regardless of whether the physicochemical boundaries chosen by every specialist differ somewhat, however, some shared conviction was obvious.

\section{Moisture}

The moisture content of honey relies upon the production season and type of weather, which directly impact the preparation, viscosity, and crystallization of honey [16]. Measuring the refractive index of honey with fixing the temperature at $20^{\circ} \mathrm{C}$ is used to decide the moisture content of honey which gives data about the stability and opposition of honey to fermentation. If the moisture content of honey is > $19 \%$, it shows undesirable honey fermentation. Thus, the low moisture content is a good sign for a more excellent and longer time span of usability of honey [13].

In Ethiopia, distinctive explorations depending on the geographical region of the nation are conducted. As indicated by Abera, et al. [12]; Meseret, et al. [17]; Birhanu[18] from Bale, West Shoa, and Guji zone of Oromia report 17.89 \pm 1.02 , $16.54 \pm 1.68$, and $14.4 \% \pm 1.5 \%$, respectively. From the northern part of the country Mekuanint and Meareg, (2019) report from the Amhara and Tigray region with an average moisture content of $18.09 \pm 1.23 \%$. Likewise, Gebru, et al. 2015 [19]; Getu and Birhan, 2014 [20] from Debre-Nazret of Tigray region and Northern Gonder inform $19.97 \%$ and $18.5 \%$ which are in agreement with USDA [21] (16-18.6\%). Getachew, et al. [22] ; Tigistu, et al. [23], from south Ethiopia report values with a range from $20.4 \%-24.8 \%$ and report the highest $(20.54 \pm 1.28$ ) and the lowest moisture value $(14.14 \pm 0.19)$.

Accordingly, investigations done in Ethiopia are summed up in Table 1 which was in good agreement with EU, FAO/ WHO, and Ethiopian standards. The moisture content reported goes from as low as $16.54 \mathrm{~g}$ to as high as $19.97 \mathrm{~g} / 100 \mathrm{~g}$ with a mean of $18.93 \mathrm{~g} \pm 1.92 \mathrm{~g}$. The entirety of the investigations was in concurrences with the discoveries of honey produced in the European Atlantic region [24] and Greek honey [2].

\section{Free acidity}

Different authors' reports all honey are somewhat acidic, this is because of the existence of organic acids [2]. Free acidity results from the fermentation of sugars to organic acids by enzymes secreted by honeybees.

The content of organic acid in honey is utilized to state the freshness of honey and separate honey as per their botanical and geographical source [26].

Citation: Berhanu S, Tadesse DM, Jorge A. (2022) Physico-chemical properties of Ethiopian Apis mellifera Honey: Review. J Agric Sc Food Technol 8(1): 038-044. DOI: https://dx.doi.org/10.17352/2455-815X.000143 
Table 1: The average value of moisture content, free acidity, and pH honey from Ethiopia is in contrast with a bunch of national, EU, and worldwide guidelines (FAO/WHO). Std $=$ Standard deviation

\begin{tabular}{|c|c|c|c|c|c|c|c|}
\hline & \multicolumn{2}{|c|}{ Moisture Content in \% } & \multicolumn{2}{|c|}{ Free acidity (meq/kg) } & \multicolumn{2}{|c|}{ pH } & Authors \\
\hline & Mean \pm Std & Range & Mean \pm Std & Range & Mean \pm Std & Range & \multirow{2}{*}{$\begin{array}{c}\text { Abera, et al. [12], Meseret, et al. [17], Tigistu, et al. [23], Gebru, et al. [19] } \\
\text { Getachew, et al. [22], Mekuanint and Meareg (2019), Addis \& Malede } \\
\text { [25], Alemayehu (2011). }\end{array}$} \\
\hline & $18.93 \pm 1.92$ & 16.54-19.97 & $28.67 \pm 3.32$ & 34.57-24.39 & $3.94 \pm 0.14$ & $4.2-3.8$ & \\
\hline $\begin{array}{l}\text { Ethiopia } \\
\text { standard }\end{array}$ & \multicolumn{2}{|c|}{ - } & \multicolumn{2}{|c|}{$<40$} & \multicolumn{2}{|c|}{ - } & $\begin{array}{l}\text { Quality Standard Authority of Ethiopia } \\
\text { (QSAE) (2005). }\end{array}$ \\
\hline $\mathrm{FAO} / \mathrm{WHO}$ & \multicolumn{2}{|c|}{$21-23$} & \multicolumn{2}{|c|}{40} & \multicolumn{2}{|l|}{ - } & FAO (2010). \\
\hline EU & \multicolumn{2}{|c|}{21} & \multicolumn{2}{|c|}{40} & \multicolumn{2}{|l|}{-} & The Council of the European Union (2002) [15] \\
\hline
\end{tabular}

The free acidity of Ethiopian honey revealed by the various author with a mean estimation of $29.74 \pm 2.20$ Mekuanint and Meareg, (2019), 34.57 \pm 4.80 Abera, et al. [12], 27.0 \pm 3.07 , Adgaba, et al. [11], 29.66 $\pm 6.13 \mathrm{meq} / \mathrm{kg}$, Meseret, et al. [17] and Gebru, et al. [19] from Tigray region report $25.95 \mathrm{meq} / \mathrm{kg}$. Thus, the average value is $28.67 \pm 3.32 \mathrm{meq} / \mathrm{kg}$. The entirety of the report is inside the perceived national $(<40 \mathrm{meq} / \mathrm{kg})$ Wedmore [27], international CSA, (2012) (5-54meq/kg), and WHO/FAO (<40meq/kg) Estevinho, et al. [28] guidelines of honey quality. Adgaba, et al. [11] report a smaller value (27.0meq $/ \mathrm{kg})$, and the higher value $(34.57 \mathrm{meq} / \mathrm{kg})$ is reported by [12] with a mean estimation of $18.93 \mathrm{meq} / \mathrm{kg}$.

All of the research achieved in Ethiopia for organic acid were within the acceptable range of National, EU, FAO/WHO set as the limit of $<50 \mathrm{meq} / \mathrm{kg}$ which is a prerequisite for blossom honey [15]. The total solids of honey organic acids are much less than $0.5 \%$, however, it's very useful for aroma, honey taste, color, and honey renovation and permits micro-organisms to be complex to grow. These organic acids are directly obtained from nectar (citric oxalic and malic) and some of them are derived from sugar by enzyme secreted by honeydew sugars by the action of enzymes (oxalic and others) [29,30].

\section{Ash content}

Estimating ash content honey is directly related to assessing the mineral substance present in honey [2].

The mineral substance of honey relies upon soil nature, kinds of plants, ecological condition, and origin of the floral plant, which is an immediate pointer of contamination of climate and geological source. Bogdanov, [31]; affirmed pollen gathered by the honey bees during scrounging on the plants is the principal factor that influences the ash (mineral) content of honey, which fluctuates from 0.02 to marginally more than $1 \%$ for flower honey.

In Ethiopia, there was a huge contrast in the ash content of honey in the region. Mean value $0.34 \pm 0.05$ (from Gambella), $0.39 \pm 0.04$ (from Bale), and 0.21 \pm 0.01 (from Amhara and Tigray
Regions) reported by Berhe, et al. 2018 [32]; Abera, et al. 2017 [12]; Mekuanint and Meareg, (2019) which summarized in Table 2. The average ash content of Ethiopian honey is $0.317 \pm 0.133$ with a range of $0.14-0.47 \%$. Information on the ash content of honey is utilized as a boundary to assess the dietary benefit of honey. This affirmation was demonstrated by analyzing honey samples from various regions of Ethiopia, whose values were certified with other writing information. Typically, potassium is a major contributor to mineral content, as reported by a different author, and from the ash content, the average value of Ethiopian honey is acceptable by FAO/WHO.

\section{Hydroxymethylfurfural (HMF)}

Hydroxymethylfurfural (HMF) is broadly recognized as a boundary of honey deterioration. Honey put away for a long time has high HMF content which is formed by the breakdown of monosaccharides, particularly fructose. Honey bee species, season, $\mathrm{pH}$ of honey, stockpiling condition, and heating are the factor that influences the HMF substance of Honey [19,33,34] report higher value $(14.99 \mathrm{mg} / \mathrm{kg})$ from Tigray, Berhe, et al. [32] from Gambella report $9.91 \pm 2.64 \mathrm{mg} / \mathrm{kg}$. Engidaw, et al. [35], work impact of season on the HMF of honey and report season also one factor which influences HMF content of honey. Hence the average HMF of Ethiopian Honey is $9.44 \mathrm{mg} / \mathrm{kg}$ \pm 7.11 and research done in HMF in Ethiopia is summarized in Table 2. Appropriately, the mean HMF value of honey as far as production seasons in a year changed from $16.1-20.3 \mathrm{mg} /$ $\mathrm{kg}$. The entirety of the honey falls on national and FAO/WHO acceptable range.

\section{Electrical conductivity}

The electrical conductivity of honey is identified with its capacity to move electric flow, this is because of the mineral, salts, organic, and other components which exist in honey [11]. This parameter compliments different boundaries utilized in the assurance of honey botanical origin [14]. Chefrour, et al. [37] report electrical conductivity is linked to honey ash content and alkalinity which is widely used to differentiate between

Table 2: The average value of HMF, ash content, and electrical conductivity honey from Ethiopia in contrast with a bunch of national, EU, and worldwide guidelines (FAO/WHO).

\begin{tabular}{|c|c|c|c|c|c|c|}
\hline \multicolumn{2}{|c|}{ HMF (mg/kg) } & \multicolumn{2}{|c|}{ Ash Content (\%) } & \multicolumn{2}{|c|}{$\begin{array}{l}\text { Electrical Conductivity } \\
\qquad(\mathrm{mS} / \mathrm{cm})\end{array}$} & Authors \\
\hline Mean \pm Std & Range & Mean \pm Std & Range & Mean \pm Std & Range & \multirow{2}{*}{$\begin{array}{l}\text { Engidaw, et al. [35], Nigussie, et al. [36], Abera, et al. [12], Meseret, et al. [17], Gebru, et al. } \\
\text { ([19], Mekuanint and Meareg (2019), Alemayehu (2011), Adgaba, et al. [11], Abera, et al. } \\
\text { (2013), Berhe, et al. [32], Dubero, et al. (2015), Tigistu, et al. [23]. }\end{array}$} \\
\hline $9.46 \pm 7.11$ & $16.5-0.84$ & $0.32 \pm 0.13$ & $0.14-0.50$ & $0.41 \pm 0.16$ & $0.21-0.7$ & \\
\hline
\end{tabular}

\begin{tabular}{c|c|c|c}
$\begin{array}{c}\text { Ethiopia } \\
\text { standard }\end{array}$ & $<40$ & $<0.6$ & - \\
\hline FAO/WHO & 80 & - & - \\
\hline EU & 40 & $<0.6$ & $<0.8 \mathrm{mS} / \mathrm{cm}$ \\
\hline
\end{tabular}

Quality Standard Authority of Ethiopia (QSAE)(2005).

FAO (2010)/Codex Alimentarius (2001).

The Council of the European Union [15].

Std $=$ Standard deviation 
honeydew and blossom honey and as well for the classification of unifloral honey.

Blossom honey has electrical conductivity lower than $0.8 \mathrm{mS} / \mathrm{cm}$, yet honeydew should be higher than $0.8 \mathrm{mS} / \mathrm{cm}$ as per. Electrical conductivity in all regional parts of the country report ranged from $0.21 \mathrm{mS} / \mathrm{cm} \mathrm{[36]} \mathrm{to} 0.70 \mathrm{mS} / \mathrm{cm}$ (Abera, et al. 2013).

In general, the average values are 0.410 .16 which is below the maximum limit of $0.8 \mathrm{mS} / \mathrm{cm}$ set by the Codex Alimentarius (Codex, 2001) and FAO/WHO.

\section{pH (Power of Hydrogen)}

Honey $\mathrm{pH}$ has been helpful in the determination of its geographical starting point and corresponded with an affirmation of adulteration of honey [38]. The $\mathrm{pH}$ of Honey is ranging from 3.4 to 6.4. The average $\mathrm{pH}$ value of Ethiopian honey was $3.94 \pm 0.14$, with a most minimal worth detailed by Abera, et al. [12] (3.79) for 320 kinds of honey gathered from Ethiopia and the highest value is reported by Alemayehu (2011) (4.37) from silite zone.

Although the $\mathrm{pH}$ limit has not yet been described by the Regulatory Committees, a pH level between 3.2 and 4.5 and the natural acidity of the honey inhibit the growth of microorganisms, as the optimum $\mathrm{pH}$ for most organisms is between 7.2 and $7.4[8,9]$. The $\mathrm{pH}$ of honey from Kenya and Sudan was reported with a mean of $4.1 \pm 0.3$ and $3.6 \pm 0.6$ Nzano, et al. [39]; Ishraga, et al. (2017) separately. Lower $\mathrm{pH}$ is linked with the fermentation of sugars present in the honey into organic acid. Blossom honey has a $\mathrm{pH}$ range from 3.5 to 4.5 yet honey with a $\mathrm{pH}$ over 5 to be of low quality [37]. Therefore, Ethiopian honey has delegated Blossom honey.

\section{Sugar content}

As a food service, honey has been utilized for quite a long time as a sugar and human energy source. Carbohydrates as sugars are the significant constituents of honey, from which fructose and glucose (reducing sugars) are the primary contributors [40]. Sugars contained in pollen are principally sucrose, glucose, and fructose, yet their relative proportions are usually rather variable; in any case, they are very reliable for certain botanical families [41].

Numerous investigations are led by researchers in Ethiopia for sugar compositions of honey which were inside the satisfactory scope of $\mathrm{EU}, \mathrm{FAO} / \mathrm{WHO}$, and national set. In Tigray and Amhara, Mekuanint and Meareg, (2019) were done honey research acquired from the farmers' hives and reported sucrose content within arrange of $1.35 \%-5.96 \%$ which were in acceptable concurrence with Alemu, et al. 2013 [42] (1.0\%$5.2 \%)$ and Eyobel, et al. (2017) (2.28\%- 5.72\%) and reducing sugar with mean values of $(64.93 \pm 1.53)$ which summarized in Table 3.

Then again, research led by Berhe, et al. [32] from Gambella, Abera, et al. (2013) from Bale, Meseret, et al. [17] from west Shewa Oromia, Alemayehu, (2011) from siliti woreda, Abera, et al., [11]; Adgaba, et al. [12] for honey gathered from various part of the nation detailed mean value of sucrose and reducing sugar were discovered to be 4.1 and 69.04, 2.4 and 69.48, 1.54 and $71.84,4.1$ and $69.04,2.43$ and 69.48 and 3.7 and $67.4 \%$, independently. Mohammed [43] from Sudan and Cantarelli, et al. [44] from Argentinean reported sucrose content of 5.8$8.7 \%$ and $4.05 \%$, individually.

Generally, as per the prerequisite set by EU/FAO/WHO for honey quality $(<5 \mathrm{~g} / 100 \mathrm{~g}$ sucrose) and $(>65 \mathrm{~g} / 100 \mathrm{~g}$ reducing sugar) the above-demonstrated honey satisfies the foreordained guideline with a mean value and standard deviation of $2.75 \pm 1.11$ and $70.46 \pm 3.95$. Moreover, fructose and glucose in honey are credited to predetermine phases of honey ripeness nectar sources in various geological areas, and it ascribes to decide the sugar composition of honey. In general [8], the flower utilized by the honey bee, ecological and climatic conditions are a primary contributor to the sugar composition of honey [45]. The dietary, physical, and synthetic properties of honey-like thickness, hygroscopicity, explicit turn, and energy principally rely upon the sugar structures [46].

\section{Minerals and water insoluble solids}

In Apis mellifera honey, the mineral content of the honey is frequently reported to relate to the dietary advantage of honey [19]. Pollen, wax, honeycomb debris, honey bees, and filth particles are water-insoluble solid constituents of honey. In Ethiopia, Abera, et al. [12] was carried out research on honey gathered from the whole part of the country and reported the Potassium level of monofloral honey ranged from $1.136 \pm 5$ to $0.272 \pm 10 \mathrm{~g} / \mathrm{kg}$. Also, in Tigray, studies directed by Nigussie, et al. [36] for honey samples gathered from the known apiculture areas report $\mathrm{Cu}(13.99 \mathrm{mg} / \mathrm{kg}$ for Adigrat), $\mathrm{Ni}(2.612 \mathrm{mg} / \mathrm{kg}$ for Abiy Adi), and Fe (12.73 mg/kg for Hagereselam). The estimation of water-insoluble solids is imperative to distinguish honey pollutions that are higher than the allowed maxima.

The accessible information on water-insoluble solid revealed the lowest value of $0.12 \%$ in Harenna forest from Oromia by Abera, et al. (2013), the greatest value reported by Alemayehu, (2011) $(0.26 \%)$ and $0.21 \%$ from the Tigray region

Table 3: The average value of Reducing Sugar, Sucrose, and Water-insoluble solids from Ethiopia is in contrast with a bunch of national, EU, and worldwide guidelines (FAO/WHO).

\begin{tabular}{|c|c|c|c|c|c|c|c|}
\hline & \multicolumn{2}{|c|}{ Reducing Sugar (\%) } & \multicolumn{2}{|c|}{ Sucrose (\%) } & \multicolumn{2}{|c|}{ Water-insoluble solids (\%) } & Authors \\
\hline & Mean \pm Std & Range & Mean \pm Std & Range & Mean \pm Std & Range & \multirow{2}{*}{$\begin{array}{c}\text { Berhe, et al. [32], Abera, et al. [12], Meseret, et al. [17], Gebru,et al. [19], Mekuanint } \\
\text { and Meareg, (2019), Alemayehu, (2011), Adgaba, et al. [11], Abera, et al. 2013, } \\
\text { Tigistu, et al. [23]. }\end{array}$} \\
\hline & $70.46 \pm 3.50$ & $64.9-76.4$ & $2.75 \pm 1.1$ & $1.22-3.7$ & $0.20 \pm 0.07$ & $0.12-0.21$ & \\
\hline
\end{tabular}

\begin{tabular}{c|c|c|c|c|}
\hline $\begin{array}{c}\text { Ethiopia } \\
\text { Standard }\end{array}$ & $>65$ & $<10$ & $<0.1$ & Quality Standard Authority of Ethiopia (QSAE) (2005). \\
\hline FAO/WHO & $>65$ & $5-10$ & - & FAO (2010). \\
\hline EU & $>65$ & 5 & $<0.1$ & The Council of the European Union [15]; Codex Alimentarius (2001). \\
\hline
\end{tabular}

Std $=$ Standard deviation 
which was announced by [19]. The water-insoluble solid substance has been set to be not more than 0.1max in Apis mellifera honey in the national standard. The average value for the water-insoluble solid of Ethiopian honey was $0.196 \pm 0.071$. This outcome was under the world limit esteem $(0.26 \%-$ $0.84 \%$ ) but above the national standard $(0.1 \%)$ ) this is on the grounds that the pure whiteness of honey.

\section{Antioxidant properties}

Antioxidants, as their name indicates, are chemicals that inhibit oxidation. Antioxidants are therefore required to act as radical scavengers, which transform reactive radicals to less reactive forms and prevent reactions with body cells in order to avoid cell harm (Kumar, 2014).

Phytochemicals such as polyphenols are the main contributors to the effects of antioxidants in honey, according to Khalil, et al. [47]. Polyphenols are composed of flavonoids and phenolic acids, which together with other components such as organic acids, amino acids, proteins, carotenoids, enzyme glucose oxidase, and catalase are attributed to the antioxidant properties of honey. The possible relationship between antioxidant activity (as measured by the oxygen radical absorption capacity assay) and the levels of different honey components have been studied [48].

\section{Phenolic compound}

Phenolic compounds are fragrant compounds with at least one hydroxyl group that act as antioxidants, disposing of free radicals and inhibiting lipid oxidation. In view of their chemical structure, they can be partitioned hydroxybenzoic and hydroxycinnamic acids and there are around 10,000 phenolic compounds [49]. They can be separated as flavonoids and nonflavonoids, flavonoids (phenolic acid) have bioactive capacities which found in plant and food, serve as secondary metabolites needed for the ordinary cycle of normally happening plants (Andersen and Markham, 2006).

In Ethiopia, the total polyphenol content of the honey mentioned by Sime, et al. [50] ranged from $330 \pm 38 \mathrm{mg}$ GAE $/ 100$ g (from bore) to $610 \pm 5 \mathrm{mg}$ GAE / $100 \mathrm{~g}$ (from woliata soddo); Adgaba, et al. [11] also mentioned a range of $233.3 \pm 24.0 \mathrm{mg}$ GAE $/ \mathrm{kg}$ to $693.3 \pm 26.8 \mathrm{mg}$ GAE $/ \mathrm{kg}$. Additionally, from west Shewa Oromia Mesert, et al. (2018) stated the highest mean value $(196.54 \pm 6.47 \mathrm{GAE} / 100 \mathrm{~g})$, and the lowest mean value (161.16 \pm 6.46$)$, and Mekuanint and Meareg (2019) also reported honey from the Amhara Region Showed higher total phenolic content and better antioxidant activity than from Tigray with the highest mean value of $196.54 \pm 6.74 \mathrm{mg}$ GAE $/ \mathrm{kg}$ and the lowest value $161.15 \pm 6.48 \mathrm{mg} \mathrm{GAE} / \mathrm{kg}$. In general, the total phenolic contents of Ethiopian honey had been numerous from 423.925 to $264 \pm 96$ (higher mean value) to $221.33 \pm 79.97$ (lower mean value).

Most phenolic compounds studied by several authors are vanillic acid, caffeic acid, syringic acid, p-coumaric acid, ferulic acid, quercetin, kaempferol, myricetin, pinobanksin, pinocembrin, chrysin, ellagic acid, galangin, 3-hydroxybenzoic acid, chlorogenic acid, 4- hydroxybenzoic acid, rosmarinicacid, gallic acid, hesperetin, benzoic acid and others [40,51].
Antioxidant, antimicrobial, antiviral, their capacity to scavenge or reduce the formation of free radicals and anticancer activities of the honey are affected by the floral foundation, concentration and form of polyphenolic substances [52].

\section{Enzyme activity}

Honey holds small amounts of enzymes of which diastase and invertase are the most important because they are carefully chosen for the validation of honey quality. In addition, the $\alpha$-and $\beta$-glucosidase, catalase, acid phosphatase, and glucose oxidase are also the most common enzyme found in honey [8]. Ortiz-Valbuena, et al. [53]; Sabatini [46] report, the enzymatic content of honey is associated with proline amino acids which control nectar enzymatic transfer, basically, nectar transformation in honey allow secretion of invertase.

In addition, catalase and acid phosphatase are derived from pollen, honeydew, or nectar. Enzymes, actually serve as an indicator of aging and overheating (thermolabile), subsequently, their performance is minimized in the situation. Basically, nectar abundance flow and transformation degree, state and strength of the colony, seasonal activity, temperature and state, and strength of the colony are a factor that affects the enzyme content in honey [54-56].

In Ethiopia, studies led by Gebru, et al. [19] report a mean value of diastase content $6.25 \mathrm{DN}$ (with a mean of $8.10 \mathrm{DN}$ for modern hive and 6.60 for traditional hive) from Tigray Region for honey gathered from known apiculture regions. This report is beneath as far as possible set by EU and FAO/WHO ( $>8 \mathrm{DN})$. Starch and dextrins are hydrolyzed by diastase to shape more modest sugar and the content of diastase activity in honey may vary.

The physiological time of the colony, the nectar assortment period, age of honey bee, and a large amount of nectar flow and its sugar content in light of the fact that a high movement of concentrated nectar prompts a lower catalyst substance and pollen utilization [55-64]. Then again, a few investigations were directed by various researchers like by Fredrick, et al. (2013), from Kenya which report diastase content (4.5 $\pm 1.04-$ $11.2 \pm 0.44 \mathrm{DN}$ ) in acceptable range by national and $\mathrm{EU}$ and $\mathrm{FAO} /$ WHO.

\section{Conclusion and recommendation}

In this review, most of the physical and chemical characterized (moisture contents, reducing sugars (glucose and fructose), free acidity, $\mathrm{pH}, \mathrm{HMF}$, enzyme activity, phenolic compounds, minerals, and water-insoluble solid and antioxidant activity) results of the honey are agreed with the national and international set quality standards set by Quality Standard Authority of Ethiopia, Codex Alimentarius Commission and EU Council.

It can be concluded that Ethiopian honey is a good quality bee product for the local and international market. Honey from the northern part (Amhara and Tigray region) of the country exhibited better total phenolic content and higher antioxidant activity. However, most of the research findings done in the 
other regional part of the country do not focus on the medicinal value of honey. Hence, more research would be important to focus on honey from medicinal plants and to establish the possible relations between the bioactive substances in plant parts and their nectar.

\section{References}

1. Anklam E (1998) A review of the analytical methods to determine the geographical and botanical origin of honey. Food chem 63: 549-562. Link: https://bit.ly/3nzBhnG

2. Karabagias IK, Badeka A, Kontakos S, Karabournioti S, Kontominas MG (2014) Characterisation and classification of Greek pine honeys according to their geographical origin based on volatiles, physicochemical parameters and chemometrics. Food Chem 146: 548-557. Link: https://bit.ly/3qBuT19

3. Manyi-Loh CE, Clarke AM, Ndip N (2011) An overview of honey: Therapeutic properties and contribution in nutrition and human health. Afr $\mathrm{J}$ Microbiol Res 5: 844-852. Link: https://bit.ly/33EDMOB

4. Wang J, Li QX (2011) Chemical composition, characterization, and differentiation of honey botanical and geographical origins. Adv Food Nutr Res 62: 89-137. Link: https://bit.ly/3GEMoU9

5. Uthurry CA, Hevia D, Gomez-Cordoves C (2011) Role of honey polyphenols in health. Journal of ApiProduct and ApiMedical Science 3: 141-159. Link: https://bit.ly/3GEMQ4N

6. Khali MI, Alam N, Moniruzzaman M, Sulaiman SA, Gan SH (2011) Phenolic acid composition and antioxidant properties of Malaysian honeys. J Food Sci 76: C921-C928. Link: https://bit.ly/3FFw9oe

7. Nakajima VM, Macedo GA, Macedo JA (2014) Citrus bioactive phenolics: Role in the obesity treatment. LWT-Food Sci Technology 59: 1205-1212. Link: https://bit.ly/3FCfCBK

8. da Silva PM, Gauche C, Gonzaga LV, Costa ACO, Fett R (2016) Honey: Chemical composition, stability and authenticity. Food Chem 196: 309-323. Link: https://bit.ly/3FQs06d

9. Machado De-Melo AA, Almeida-Muradian LBD, Sancho MT, Pascual-Maté A (2018) Composition and properties of Apis mellifera honey: A review. J Apicul Res 57: 5-37. Link: https://bit.ly/3GGJmyq

10. Livestock CSA (2017) livestock characteristics, agricultural sample survey Addis Ababa, Ethiopia. Statistical Bulletin 2: 9-13

11. Adgaba N, Al-Ghamdi A, Sharma D, Tadess Y, Alghanem SM, et al. (2020) Physico-chemical, antioxidant and anti-microbial properties of some Ethiopian mono-floral honeys. Saudi J Biological Sci 27: 2366-2372. Link: https://bit.ly/3FFxwDo

12. Abera B, Haki GD, Birringer M, Borck H, Lee YC, et al. (2017) Sugar profile and physicochemical properties of Ethiopian monofloral honey. Int $\mathrm{J}$ Food Properties 20: 2855-2866. Link: https://bit.ly/3Kxx51Z

13. El Sohaimy SA, Masry SHD, Shehata MG (2015) Physicochemical characteristics of honey from different origins. Annals Agricul Sci 60: 279287. Link: https://bit.ly/3qCXhAd

14. Yücel $Y$, Sultanoglu $P(2013)$ Characterization of honeys from Hatay region by their physicochemical properties combined with chemometrics. Food Biosci 1: 16-25. Link: https://bit.ly/33oeyEy

15. Council EU (2002) Council Directive 2001/110/EC of 20 December 2001 relating to honey. Official $J$ European Communities L 10: 47-52. Link: https://bit.ly/3fBLGLe

16. Miklyaev M, Jenkins GP, Barichello RR (2014) Honey production in Ethiopia: A costbenefit analysis of modern versus traditional beekeeping technologies. Cambridge Resources International Inc, UK. Link: https://bit.ly/3FE1ZBR

17. Meseret G, Abera B, Kaleab B, Abule E (2018) Physicochemical and Antioxidant Properties of Honey and Pollen from West Shoa, Ethiopia. Thesis submitted to the Center of Food Science and Nutrition downloaded from academic edu. University of Adiss Ababa.
18. Birhanu TA (2015) Honeybee production and honey quality assessment in Guji Zone, Ethiopia. J Food Processing Technology 6. Link: https://bit.ly/3fCi5kS

19. Gebru Equar BA, Lemma H, Amare S (2015) Physicochemical Characterization of Honey from Debre-Nazret Kebelle of Tigray Region, Ethiopia. World Applied Sciences Journal 33: 1806-1814. Link: https://bit.ly/3GEQ0p7

20. Getu A, Birhan M (2015) Chemical analysis of honey and major honey production challenges in and around Gondar, Ethiopia.

21. USDA (1985) "United states standards for grades of extracted honey," in Agricultural Marketing Service Fruit and Vegetable Division Processed Products Branch, Department of Agriculture, Washington, DC, USA, 5th edition. Link: https://bit.ly/3ldflHO

22. Getachew A, Gizaw H, Assefa D, Tajebe Z (2014) Physico-chemical properties of honey produced in Masha, Gesha, and Sheko districts in Southwestern Ethiopia. Current Res Agricu Sci 1: 110-116. Link: https://bit.ly/3rsayeb

23. Tigistu T, Worku Z, Mohammed A (2021) Evaluation of the physicochemical properties of honey produced in Doyogena and Kachabira Districts of Kembata Tambaro zone, Southern Ethiopia. Heliyon 7: e06803. Link: https://bit.ly/3A9vCK9

24. Escuredo O, Míguez M, Fernández-González M, Seijo MC (2013) Nutritional value and antioxidant activity of honeys produced in a European Atlantic area. Food chem 138: 851-856. Link: https://bit.ly/3tE2gT4

25. Addis G, Malede B (2014) Chemical analysis of honey and major honey production challenges in and around Gondar. Ethiopia. Academic J Nutrition 3: 6-14. Link: https://bit.ly/3fBtUYA

26. Diafat AEO, Benouadah A, Bahloul A, Meribai A, Mekhalfi H, et al. (2017) Physicochemical properties and pollen analyzes of some Algerian honeys. Int Food Res J 24: 1453-1459. Link: https://bit.ly/352Hfar

27. Wedmore EB (1955) The accurate determination of the water content of honeys: Part I. Introduction and results. Bee world 36: 197-206. Link: https://bit.ly/33Jjtj4

28. Estevinho L, Pereira AP, Moreira L, Dias LG, Pereira E (2008) Antioxidant and antimicrobial effects of phenolic compounds extracts of Northeast Portugal honey. Food Chem Toxicol 46: 3774-3779. Link: https://bit.ly/33QNH3P

29. Mato I, Huidobro JF, Simal-Lozano J, Sancho MT (2006) Rapid determination of nonaromatic organic acids in honey by capillary zone electrophoresis with direct ultraviolet detection. J Agric Food Chem 54: 1541-1550. Link: https://bit.ly/3GCNKi2

30. Cherchi A, Spanedda L, Tuberoso C, Cabras P (1994) Solid-phase extraction and highperformance liquid chromatographic determination of organic acids in honey. J Chromatogr A 669: 59-64. Link: https://bit.ly/3qFB5p7

31. Bogdanov S (2017) Propolis. Composition, Health, Medicine. A Review. Bee Product Science.

32. Berhe A, Tesfaye E, Terle D (2018) Evaluation of physicochemical properties of honey bees (Apis mellifera) in Godere Woreda, Gambella, Ethiopia. American J Food Sci Technology 6: 50-56. Link: https://bit.ly/3AkJKR6

33. Mar Cavia M, Alvarez C, Huidobro JF, Fernández-Muiño MA, Teresa Sancho $M(2008)$ Evolution of hydroxymethylfurfural content of honeys from different climates: Influence of induced granulation. International J Food Sci Nutrition 59: 88-94. Link: https://bit.ly/3FFWUcn

34. Turhan I, Tetik N, Karhan M, Gurel F, Tavukcuoglu HR (2008) Quality of honeys influenced by thermal treatment. LWT-Food Science and Technology 41 : 1396-1399. Link: https://bit.ly/3nA8cJ6

35. Engidaw D, Alemayehu K, Mustofa S, Tilahun A (2020) Effect of season on the major physico-chemical parameters of honey product. Food Environment Safety J 19.

36. Nigussie K, Subramanian PA, Mebrahtu G (2012) Physicochemical analysis of Tigray honey: An attempt to determine major quality markers of honey. Bulletin Chemical Society Ethiopia 26. Link: https://bit.ly/3nETy31

37. Chefrour C, Draiaia R, Tahar A, Kaki YA, Bennadja S, et al. (2009).

Citation: Berhanu S, Tadesse DM, Jorge A. (2022) Physico-chemical properties of Ethiopian Apis mellifera Honey: Review. J Agric Sc Food Technol 8(1): 038-044. DOI: https://dx.doi.org/10.17352/2455-815X.000143 
Physicochemical characteristics and pollen spectrum of some northeast Algerian honeys. African J Food Agric Nutr Develop 9. Link: https://bit.ly/33MBUUa

38. Gomes S, Dias LG, Moreira LL, Rodrigues P, Estevinho L (2010) Physicochemical, microbiological and antimicrobial properties of commercial honeys from Portugal. Food Chem Toxicol 48: 544-548. Link: https://bit.ly/3rsGrTP

39. Nzano PN, Nyamasyo GHN, Asiko GA (2013) Beekeeping hive technology visá-vis honey quality in Kenya. In XXXXIII International Apicultural Congress.

40. Alvarez-Suarez JM, Gonzalez-Paramas AM, Santos-Buelga C, Battino M (2010) Antioxidant characterization of native monofloral Cuban honeys. J Agric Food Chem 58: 9817-9824. Link: https://bit.ly/3KIWzz9

41. Maurizio A (1975) Microscopy of honey. Honey: A Comprehensive Survey. E. Crane, ed. Link: https://bit.ly/3FI60u6

42. Alemu T, Seifu E, Bezabih A (2013) Physicochemical properties of honey produced in Sekota district, northern Ethiopia. Int Food Res J 20: 3061-3067. Link: https://bit.ly/3GHmFKx

43. Mohammed SA, Ali EE (2007) Preliminary test for the occurrence of adulterants in commercial Sudanese honeys. Sudan J Agric Res (Sudan).

44. Cantarelli MA, Pellerano RG, Marchevsky EJ, Camiña JM (2008) Quality of honey from Argentina: study of chemical composition and trace elements. Link: https://bit.ly/33ABQa2

45. Tornuk F, Karaman S, Ozturk I, Toker OS, Tastemur B, et al. (2013) Quality characterization of artisanal and retail Turkish blossom honeys: Determination of physicochemical, microbiological, bioactive properties and aroma profile. Industrial Crops Products 46: 124-131. Link: https://bit.ly/3Koi5Dm

46. Sabatini AG (2007) Origine, composizione e proprieta(AG Sabatini, L. Botolotti, \& GL Marcazzan, Eds.). Bologna-Milano: Avenue Media.

47. Khalil MI, Sulaiman SA, Boukraa L (2010) Antioxidant properties of honey and its role in preventing health disorder. Open Nutraceuticals J 3: 6-16. Link: https://bit.ly/3lgL4af

48. Gheldof N, Wang XH, Engeseth NJ (2002) Identification and quantification of antioxidant components of honeys from various floral sources. J Agric Food Chem 50: 5870-5877. Link: https://bit.ly/34SLOPw

49. Challacombe CA, Abdel-Aal ESM, Seetharaman K, Duizer LM (2012) Influence of phenolic acid content on sensory perception of bread and crackers made from red or white wheat. Journal of Cereal Science 56: 181-188. Link: https://bit.ly/3qDI5UA

50. Sime D, Atlabachew M, Abshiro MR, Zewde T (2015) Total phenols and antioxidant activities of natural honeys and propolis collected from different geographical regions of Ethiopia. Bull Chem Soc Ethiopia 29: 163-172. Link: https://bit.ly/3tMYd60

51. Trautvetter S, Koelling-Speer I, Speer K (2009) Confirmation of phenolic acids and flavonoids in honeys by UPLC-MS. Apidologie 40: 140-150. Link: https://bit.ly/33osxu5

52. Sghaier MB, Skandrani I, Nasr N, Franca MGD, Chekir-Ghedira L, et al. (2011). Flavonoids and sesquiterpenes from Tecurium ramosissimum promote antiproliferation of human cancer cells and enhance antioxidant activity: A structure- activity relationship study. Environ Toxicol Pharmacol 32: 336348. Link: https://bit.ly/3Ko5gcd

53. Valbuena AO, Maeso MCF, de la Torre ESM (1996) Principales características de la miel de La Alcarria. Consejería de Agricultura y Medio Ambiente de la Junta de Comunidades de Castilla-La Mancha.

54. Maurizio A (1962) From the raw material to the finished product: honey. Bee World 43: 66-81. Link: https://bit.ly/3lc6x46

55. Oddo LP, Piazza MG, Pulcini P (1999) Invertase activity in honey. Apidologie 30: 57-65. Link: https://bit.ly/3GJw5VR

56. White JW (1979b) Physical characteristics of honey. In E.E. Crane (Ed.), Honey: A comprehensive survey 207-239. London: Heinemann.

57. Aggrawal M, Rohrer J (2017) HPAE-PAD determination of carbohydrates in honey to evaluate samples for quality and adulteration. Link: https://bit.ly/3lkKXL4

58. Brown M, Antle J, Backlund P, Carr E, Easterling WE, et al. (2015) Climate change, global food security and the US food system. Link: https://bit.ly/3fBwl83

59. Gobessa S, Seifu E, Bezabih A (2012) Physicochemical properties of honey produced in the Homesha district of Western Ethiopia. J Apicul Sci 56: 33-40. Link: https://bit.ly/3Ki2vct

60. Ibrahim IG, Onsa TO, Khalafalla AE, Ishag HI, Yassin SO, et al. (2017) Quality Assessment of Bee Honey from Western Sudan Regions. Sudan J Vet Res 32: $1-5$.

61. Kebede A, Adgaba N (2011) Honey Bee Production Practices and Honey Quality In Silti Wereda Ethiopia (Doctoral dissertation, Haramaya University) Link: https://bit.ly/33qKQyK

62. Leta S, Mesele F (2014) Spatial analysis of cattle and shoat population in Ethiopia: growth trend, distribution and market access. Springe rPlus 3: 1-10 Link: https://bit.ly/33Htdu9

63. Lewoyehu M, Amare M (2019) Comparative evaluation of analytical methods for determining the antioxidant activities of honey: A review. Cogent Food Agric 5: 1685059. Link: https://bit.ly/3FGHjsU

64. Nganga F, Onditu A, Gachanja A, Ngumba E (2013) Physicochemical analysis of honey in the kenyan retail market. Food Sci Qual Manag 12: 30-36. Link: https://bit.ly/3leM9zq

\section{Discover a bigger Impact and Visibility of your article publication with}

Peertechz Publications

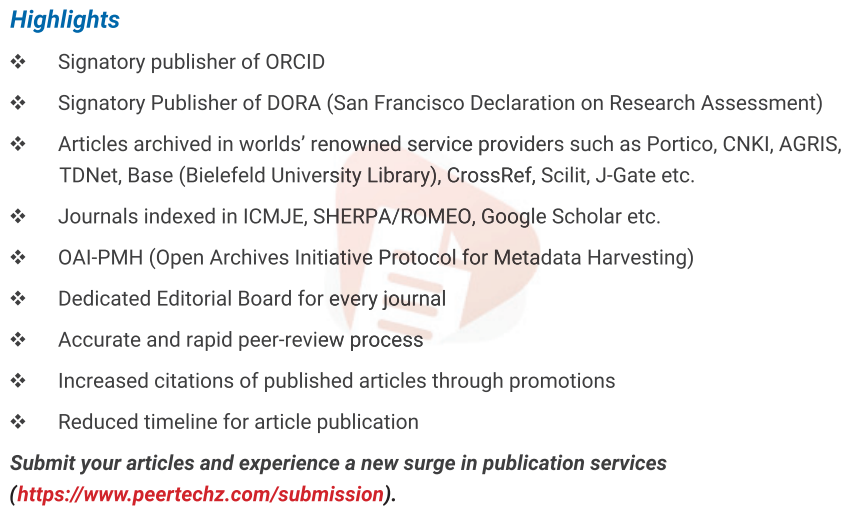

Peertechz journals wishes everlasting success in your every endeavours.

Citation: Berhanu S, Tadesse DM, Jorge A. (2022) Physico-chemical properties of Ethiopian Apis mellifera Honey: Review. J Agric Sc Food Technol 8(1): 038-044. DOI: https://dx.doi.org/10.17352/2455-815X.000143 